\title{
ANALYSIS OF IMPLEMENTATIONS INCLUSIVE EDUCATION IN SURABAYA CITY
}

\author{
Zaini Sudarto \\ Pendidikan Luar Biasa, Fakultas Ilmu Pendidikan, Universitas Negeri Surabaya \\ zainisudarto@unesa.ac.id \\ Tri Budi Sasongko \\ Pendidikan Luar Biasa, Fakultas Ilmu Pendidikan,Universitas Negeri Surabaya \\ sasongko075@gmail.com
}

\begin{abstract}
Abstrak
Implementasi Pendidikan inklusif di kota Surabaya telah di awali sejak tahun 2009 hingga saat ini tahun 2020, yaitu di 20 SD Kota Surabaya hingga sekarang berjumlah 50 SD Negeri dan 5 SD swasta, 20 SMP Negeri, 3 SMP Swasta, serta 2 SMA Negeri dan 2 SMK Negeri. Pemkot Surabaya juga memberikan perhatian lebih untuk sekolah inklusi dan layanan khusus, dengan memberikan peralatan yang dibutuhkan, seperti guru pendamping, psikolog, fasilitas kursi roda, komputer braille, alat musik, dan lain sebagainya. Pelaksanaan Penelitian dalam Rangka analisis penyelenggaraan Pendidikan Inklusif di Sekolah SDN se Kota Surabaya sudah mencapai 75\%, yaitu telah melaksanakan persiapan materi, persiapan instrumen, koordinasi dengan subyek penelitian yang telah ditentukan.
\end{abstract}

Kata Kunci: Pendidikan, Inklusif, Surabaya

\begin{abstract}
The implementation of inclusive education in the city of Surabaya has been initiated since 2009 until now in 2020, namely in 20 SD in the City of Surabaya until now there are 50 public SDs and 5 private SDs, 20 State SMPs, 3 Private SMPs, and 2 Public SMAs and 2 SMKs. Country. The Surabaya City Government also pays more attention to inclusive schools and special services, by providing the necessary equipment, such as accompanying teachers, psychologists, wheelchair facilities, braille computers, musical instruments, and so on. Research implementation in the framework of analyzing the implementation of Inclusive Education in SDN Schools throughout Surabaya has reached $75 \%$, namely having carried out material preparation, instrument preparation, coordination with predetermined research subjects.
\end{abstract}

Keyword: Education, Inclusive, Surabaya

\section{INTRODUCTION}

The government's policy in completing the Nine Years Compulsory Basic Education was encouraged by the call for International Education For ALL (EFA) announced by UNESCO as a global agreement resulting from the World Education Forum in Dakar, Sinegal in 2000, EFA completion is expected to be achieved in 2015 . 
This call is in line with the spirit and soul of Article 31 of the 1945 Constitution concerning the right of every citizen to obtain education and Article 32 of the National Education System Law Number 20 of 2003 concerning the National Education System which regulates special education and special service education.

While the equal distribution of learning opportunities for children with special needs is based on the Salamanca statement of 1994. This Salamanca statement is an extension of the goals of Education Fol All by considering the fundamental policy shifts needed to promote an inclusive education approach. Through this inclusive education it is hoped that regular schools can serve all children, including those with special educational needs. In Indonesia through the Decree of the Minister of Education and Culture No. 002 / U / 1986 has pioneered the development of a school that provides inclusive education that serves compulsory education for students with special needs.

Inclusive education is an education service system that requires children with special needs to study in nearby schools in regular classes together with their peers. Schools that provide inclusive education are ordinary schools that accommodate all students, including children with special needs. This school provides educational programs tailored to the abilities and needs of each student as well as the assistance and support that teachers can provide to make children successful

Inclusive education is a process to remove the barriers that separate students with special needs from normal students so that they can learn and work together effectively in one school. As an ideal forum, inclusive education has four meaningful characteristics, namely: (1) Inclusive education is an ongoing process in an effort to find ways to respond to the diversity of individual children, (2) Inclusive education means obtaining ways to overcome children's barriers in learning, (3) inclusive education means that children have the opportunity to attend (at school), participate and get meaningful learning outcomes in their lives, and (4) Inclusive education is intended for children who are classified as marginal, exclusive and need services special education in learning (Depdiknas, 2015).

This means that the responsibility for completing compulsory education, especially for children with special educational needs, has become the concern of various parties so that it can help children with special needs in accessing education through "learning to live together in an inclusive society". The implementation of inclusive education as referred to in the description above is currently mandatory with the issuance of Minister of National Education Regulation Number 70 of 2009 concerning "Inclusive Education for students who have disabilities and have the potential for intelligence and / or special talents". In a broader context, inclusive education can also be interpreted as a form of educational reform that emphasizes non-discrimination. Since the promulgation of the Salamanca Declaration, the emergence of various forms of terms related to 
institutional forms and educational services intended for those with disabilities such as Normalization and Mainstreaming Integration, Least Restrictive Environment, Institutionalization and Inclusion. and inclusive is one form of education services for children with special needs that are considered ideal to be implemented. In inclusive schools, students have heterogeneous abilities because students in addition to normal children are also children with physical, social, emotional and neurological sensory disabilities.

The implementation of inclusive education in the city of Surabaya has been initiated since 2009 until now in 2020, namely in 20 SD in the City of Surabaya until now there are 50 public SDs and 5 private SDs, 20 State SMPs, 3 Private SMPs, and 2 Public SMAs and 2 SMK Country. Another effort that has been made in relation to the implementation of Inclusive Education is by disseminating information on inclusive education so that everyone knows and understands inclusive education, so that there will be no more discrimination against children with disabilities. The Surabaya City Government also pays more attention to inclusive schools and special services, by providing the necessary equipment, such as accompanying teachers, psychologists, wheelchair facilities, braille computers, musical instruments, and so on.

\section{METHODS}

\section{A. Research Approach}

The approach used in this research is descriptive qualitative research. With this research, it is hoped that it can reveal various information with accurate and realistic descriptions. Each object will see trends, patterns of thought, irregularities, as well as the appearance of behavior and its integration. The strategy used in this research is an interpretive study. Qualitative descriptive research is used to describe existing phenomena by not providing treatment, manipulation or alteration to variables, but describing a condition as it is. The research objective is to find out about the implementation of the implementation of inclusive education in the city of Surabaya for the 2020/2021 academic year for basic education (SD) and secondary education (SMP).

\section{B. Data Sources}

The data sources in this study consisted of two kinds, namely primary data sources and secondary data sources.

1. Primary data sources are data sources that directly provide data to data collectors.

2. Secondary data source, based on written data or documentation related to inclusive implementation in Surabaya. 
According to Moloeng, (2009) with primary and secondary data sources, research is expected to obtain valid and holistic data needed in analyzing problems that are the focus of research.

\section{Data Collection Techniques}

To obtain the required data, researchers used questionnaire, interview, and observational data collection techniques.

1. Questionnaire

Addressed to GPK Teachers and Regular Teachers in 10 Inclusive SDN Schools, Questionnaire Form, closed questionnaire.

2. Interview

Interviewing is the process of obtaining information for research purposes by means of direct questions and answers between the interviewee and the interviewer. The type of interview used in this study is in-depth interviews or unsstructured interviews with the Principal of SDN Inclusive Schools in Surabaya.

3. Indirect Observation in ten Inclusive SDNs that have been determined as research subjects.

\section{Data Validity Technique}

Through the validity of the data, the credibility (trust) of qualitative research can be achieved. In this study, to obtain the validity of the data, triangulation was used. Triangulation is a data validity checking technique that utilizes something other than the data for checking purposes or as a comparison to the data (Moleong, 2007: 330). Triangulation with sources carried out in this study was to compare the results of interviews with the contents of the related documents.

\section{E. Data Analysis Techniques}

The data analysis technique in this study used a qualitative descriptive analysis technique. The data that has been obtained and collected are analyzed by making categorization in order to make it easier to interpret the data. Each data that has been categorized is linked to obtain a relationship that is used to draw conclusions. According to Patton in Moleong, (2001), data analysis, "the process of arranging the order of data, organizing it into a pattern, category and basic description". The data analysis technique used in this study was to use the following steps:

1. Data Collection

Data collection is an integral part of data analysis activities. Data collection activities in this study were to use interviews and documentation studies. 


\section{Data Reduction}

Data reduction, defined as the selection process, focuses on simplifying and transforming raw data that emerge from written records in the field. Reduction is carried out since data collection begins by summarizing, coding, searching for themes, creating clusters, writing memos and so on with the intention of setting aside irrelevant data / information.

3. Display Data

Display data is a description of a set of structured information that provides the possibility of drawing conclusions and taking action. The presentation of qualitative data is presented in the form of narrative text. The presentation can also be in the form of matrices, diagrams, tables and charts.

4. Verification and Confirmation of Conclusions

Merupakan kegiatan akhir dari analisis data. Penarikan kesimpulan berupa kegiatan interpretasi, yaitu menemukan makna data yang telah disajikan.

\section{RESULT}

This research is an evaluation research that uses qualitative methods, built on a naturalistic (post-positivistic) paradigm. The research was conducted by observing the implementation of inclusive education in 3 SD Negeri Surabaya City. In this study, it tries to understand the subject through its own frame of mind, as well as the qualitative research rules presented by Denzin and Lincoln cited by Creswell (2007).

The research was conducted from August 2020 to September 2020 which was divided into three stages of research. The first stage is pre-research activities in June 2020, the second stage in July 2020 is the preparation of research instruments consisting of three types of instruments, namely; Observation instruments, interview instruments with the Principal and questionnaire instruments for Regular Teachers and GPK. Until August 28, researchers have carried out the following research activities.

1. Observations in the field.

2. Distribution of closed questionnaires to regular teachers and GPK teachers.

3. Interview with the principal. 
Table 1. Research Activities

\begin{tabular}{|c|c|c|c|c|c|c|c|c|c|c|c|c|c|c|c|c|c|c|}
\hline \multirow[t]{3}{*}{ No } & \multirow[t]{3}{*}{ Type of activity } & \multirow{2}{*}{\multicolumn{4}{|c|}{$\begin{array}{c}\text { Juni } \\
\text { Week }\end{array}$}} & \multicolumn{4}{|c|}{ Juli } & \multicolumn{4}{|c|}{ Agustus } & \multirow{2}{*}{\multicolumn{5}{|c|}{ September }} \\
\hline & & & & & & & & ek & & & & ek & & & & & & \\
\hline & & 1 & 2 & 3 & 4 & 1 & 2 & 3 & 4 & 1 & 2 & 3 & 4 & 1 & & & 3 & 4 \\
\hline 1 & $\begin{array}{l}\text { Perception Equation, } \\
\text { Determination of research } \\
\text { subjects }\end{array}$ & & & & & & & & & & & & & & & & & \\
\hline 2 & $\begin{array}{l}\text { Arrangement of } \\
\text { instruments } \\
\text { Distribution and collection } \\
\text { of questionnaires }\end{array}$ & & & & & & & & & & & & & & & & & \\
\hline 3 & $\begin{array}{l}\text { Observation of } \\
\text { spaciousness }\end{array}$ & & & & & & & & & & & & & & & & & \\
\hline 4 & $\begin{array}{l}\text { Interview with the } \\
\text { Principal }\end{array}$ & & & & & & & & & & & & & & & & & \\
\hline 5 & $\begin{array}{l}\text { Processing and data } \\
\text { analysis }\end{array}$ & & & & & & & & & & & & & & & & & \\
\hline 6 & Preparation of reports & & & & & & & & & & & & & & & & & \\
\hline
\end{tabular}

\section{CONCLUSION}

Research implementation in the framework of analyzing the implementation of Inclusive Education in SDN Schools throughout Surabaya has reached 75\%, namely having carried out material preparation, instrument preparation, coordination with predetermined research subjects.

\section{REFERENCES}

Bandi Delphie, 2006. Pembelajaran Anak Berkebutuhan Khusus dalam Setting Pendidikan Inklusi, Bandung: PT. Refika Aditama,

Daniel P.Hallahan, dkk. 2009, Eceptional Learners: An Introduction to Special Education, Boston Pearson Educational Inc.

PSLB. 2012. Pedoman Umum Penyelenggaraan Pendidikan Inklusif. Jakarta Permen Dikbud, PLSB.

Suparno. 2008. Pendidikan Anak Berkebutuhan Khusus. Direktorat Jenderal Pendidikan Tinggi, Departemen Pendidikan Nasional.

Sudarwan Danim, 2005. Pengantar Studi Penelitian Kebijakan, Jakarta: PT. Bumi Aksara,

William N. Dunn, 2000. Pengantar Analisis Kebijakan Publik Yogyakarta: Gajah Mada University Press.

Nana Syaodih Sukmadinata, 2008. Metode Penelitian Pendidikan, Bandung: PT Remaja Rosdakarya.

LJ. Moloeng. 2009, Metodologi Penelitian Kualitatif, Bandung; PT. Remaja Rosdakarya. 